AWEJ for Translation \& Literary Studies, Volume3, Number2. May 2019

Pp.37-48

DOI: http://dx.doi.org/10.24093/awejtls/vol3no2.4

\title{
Tragedy and social drama in Arthur Miller's Death of a Salesman
}

\author{
Tahar Bayouli \\ Majmaah University, Azzulfi College of Education \\ Department of English, Saudi Arabia \\ Imed Sammali \\ Majmaah University, Azzulfi College of Education \\ Department of English, Saudi Arabia
}

\begin{abstract}
This paper examines the issue of genre classification in Death of a Salesman by focusing on the dialectic relation at the heart of the play's structure between tragedy and social drama. It argues that the tragic resolution brought to the theme of social protest and the characterization of the protagonist is what gives the play its unique place as the quintessential modern tragedy. It is concluded that tragedy and the social theme are not mutually destructive in Death of a Salesman as some critics stated. Rather, they are combined to make an intense dramatic treatment of the modern American individual's most pressing issues. Without being constrained by prescriptive standardized rules, Miller produced a dramatic form that rightly claims the status of what can be labeled a modern tragedy, appealing to modern audiences as rarely any other modern play did.
\end{abstract}

Keywords: Arthur Miller, catharsis, dramatic structure, social drama, tragedy.

Cites as: Bayouli, T., \& Sammali, I. (2019). Tragedy and social drama in Arthur Miller's Death of a Salesman. Arab World English Journal for Translation \& Literary Studies, 3 (2) 37-48.

DOI: http://dx.doi.org/10.24093/awejtls/vol3no2.4 
AWEJ for Translation \& Literary Studies Volume, 3 Number 2. May 2019

Tragedy and social drama in Arthur Miller's Death of a Salesman Bayouli \& Sammali

\section{Introduction}

The question of genre classification in relation to modern drama is all the more problematic as the experimentation and the eclecticism characterizing modern dramatic production have eroded the notion of the purity of genre. George Steiner's Death of Tragedy is an expression of the fact that "the tragedy of pure form" seems to have lived its day and to become too inadequate an expression for the age's conflicts and interrogations. Yet, it is a fact that the presence of the tragic as such is far from being dead and it still marks many modern plays, and in criticism on the other hand, the question remains a major issue for debate. Between the critical view that tragedy is a dead literary form and the belief that tragedy is needed and can still have a vital role in modern drama, Death of a Salesman stands as one of the most popular modern plays while claiming for the possibility and even the vital need for tragedy as an expression of modern man's experience. However, more than any other play, Death of a Salesman has, right from the date of its composition, never ceased to arouse controversies as to its classification as a tragedy. Indeed, Miller's play epitomized the period's preoccupation with the issue of dramatic genre and certainly fostered the debate over the relevance and legitimacy of the tragic form in modern drama.

Focusing on the interrelation between the social drama and the tragic form in Death of a Salesman, this paper deals with the paradoxes involved in claiming tragic status for a play produced in the context of the un-tragic orientations of contemporary drama, mainly social realism.

\section{Which drama for the modern stage?}

It is often stated that the history of modern drama is the history of realism and Ibsen's type of social drama is regarded as the gateway by which the theatre regained a place on the contemporary literary scene. After Ibsen, the tradition of social drama, most notably continued by Bernard Shaw and John Osborne, may certainly be qualified as serious drama but it certainly is more comic than tragic in its mood and in the generic sense. Writing towards the close of the nineteen sixties, that is a decade after the production of Death of a Salesman, Durrenmatt (1958) argued that comedy rather than tragedy was the suitable form for the modern stage:

The task of drama today, is to create something concrete, something that has form. This can be accomplished best by comedy. Tragedy, the strictest genre in art, presupposes a formed world. Comedy ... supposes an unformed world, a world being made and turned upside down, a world about to fold like ours. (p.30)

Other critics suggested a form that is a middle way between comedy and tragedy. The label "Comic tragedy" is suggested by Styan (1968 p.52) and nearly two decades earlier Samuel Beckett subtitles his play Waiting for Godot "a tragicomedy in two acts". In fact, as from the revival of drama in the late $19^{\text {th }}$ century, the general tendency has been to the blending of genres and styles. The "mixed mood" identified by Cohn (1969 p.17) in plays ranging from T.S. Eliot's Family Reunion (1939) to Beckett's Waiting for Godot (1952), is in fact a hybrid form which is essentially untragic in the strict generic sense. In Beckett's plays, which embody a turn to surrealism, meta-

Arab World English Journal for Translation \& Literary Studies 
AWEJ for Translation \& Literary Studies Volume, 3 Number 2. May 2019

Tragedy and social drama in Arthur Miller's Death of a Salesman Bayouli \& Sammali

drama and philosophical and aesthetic skepticism, tragedy figures in a parodic way and the very concept of heroism is deconstructed.

However, it is a fact that in criticism, the debate over tragedy is far from being closed, and a survey of dramatic literature would reveal that writing in the tragic vein constitutes a prominent crosscurrent in modern drama. In his survey of $20^{\text {th }}$ century dramatic literature, Schmidt (2001) identifies what he calls "the turn to tragedy" as "the form that most eloquently dramatizes the stubborn persistence of human blindness, vulnerability and error". He sees tragedy as all the more relevant in the intellectual context of "the growing self-doubt of philosophy, the questioning of reason, and of the analytical method and conceptual knowledge" (p.1). On the other hand, the issue of tragedy continues to be debated in drama criticism and the critical reception of every new serious play does concern itself with the question of whether it is or not a tragedy. Significantly, the plays for which tragic status has been claimed have widely given rise to controversies centered on the issue of generic classification. That a form of tragedy is needed in the modern age many drama critics have asserted it. Joseph Wood Crutch, as one of the most outspoken representatives of this view, wrote about "the supreme necessity in the $20^{\text {th }}$ century for the artistic creation of the ambiance and consolation of tragedy if the modern individual is to survive in terms of what has traditionally been known as "human"” as cited in Fiet (1976 p.63).

A tendency towards rethinking tragedy came to occupy more recent drama criticism and many critics are now in the belief that a modern play can achieve the stature and the role of tragedy without necessarily conforming to the strict structural standards of classical tragedy. In his seminal book The Tragic Fallacy (1929), Crutch rightly asserted: "Though tragedy is timeless, the form which it takes varies with the age which creates it, and no spiritual epoch has realized itself until it has created its tragedy, stating the gravamen of its protest and the terms of its acceptance" as cited in Fiet (1976 p.61).

Indeed, Miller's Death of a Salesman, with its enduring national and international success, stands as a living example of the type of play that modern drama can produce to respond to the 'necessity for tragedy' in the modern times. Arthur Miller's play is certainly first inscribed in the turn to realism and social drama established by Henrik Ibsen's tradition, but he also wrote it with the full belief in the relevance and the power of tragedy as a perfectly valid modern dramatic form. About Death of a Salesman, Bloom (2007) asserts, "Whether it has the aesthetic dignity of tragedy is not clear, but no other American play is worthier of the term, so far" (p.5).

A survey of modern drama would reveal that writing in the tragic mode is a characteristically American tendency, compared to the orientations of European drama to the parodic and the formless play. Eugene O’Neill, then Tennessee Williams played a crucial role in establishing this tradition of tragedy in American drama. Yet, it is Miller's Death of a Salesman, despite all the controversies it created, that unquestionably occupies the most prominent place in the rehabilitation of tragedy. The fact that it is a generically self-conscious tragedy adds to its unique importance, and its perennial popularity is itself an evidence of the validity of tragedy in the modern world.

Arab World English Journal for Translation \& Literary Studies 
AWEJ for Translation \& Literary Studies Volume, 3 Number 2. May 2019

Tragedy and social drama in Arthur Miller's Death of a Salesman Bayouli \& Sammali

Writing in the tradition of $20^{\text {th }}$ century realism, Arthur Miller meant to give his social drama the dimensions of tragedy and this is an essential element of his play's design and intent. Most important in this respect is that, in Death of a Salesman, the style and the tragic form are determined by a thematic that is primarily social. Therefore, the claimed tragic status can be instructively discussed in the light of the dialectic connection between the social theme and the tragic form. For Bentley (1976 p.183), the social theme and the tragedy are mutually destructive in Miller's play. However, this view does not seem to take into account the very conception of tragedy the play professes and discloses. It is the kind of critical judgement described by Sewall (1954) as based on a prescriptive and inhibitive conception of tragic form.

The theme and the structure of Miller's drama is pervaded by social realism in the tradition of Ibsen. Yet, Miller's intention in Death of a Salesman is also to achieve a highly intense dramatic form by giving his social theme a definitely tragic expression. His 'tragedy of the common man' constitutes a major modification of classical standards of tragedy pointing to the possibility of tragedy through adapting it to the nature of modern drama. It exemplifies Maeterlinck's view that "there is an everyday tragedy which is more real, deeper and more in keeping with our true existence than the tragedy of great adventures" (1952) as cited in Styan (1968). In introducing major changes on the classical conventions of tragedy, Miller adapted it to the modern experience, which is radically different from the experience and the world dramatized by classical tragedy. The unconventional features of tragedy in Death of a Salesman constitute an adaptation of the tragic form that become necessary once an everyday type of action and of character are introduced. Otten (1999) rightly describes such a change in modern tragedy: The differences that emerge in modern tragedy when realistically described social forces usurp the role of the gods transfigure tragedy profoundly - but not unrecognizably" (p.285). Social drama and tragedy are not mutually exclusive, they are mutually self-sustaining. In the following terms, Miller himself explains, in his essay "Tragedy and the common man" (1949), the mechanism by which tragedy becomes a powerful expression of modern man's plight and a tool of social criticism:

It is true that tragedy is the consequence of a man's total compulsion to evaluate

himself justly, his destruction in the attempt posits a wrong or an evil in his

environment and this is precisely the morality of tragedy and its lesson." (p.1).

The tragic downfall of the protagonist is thus meant to be an indictment of the social forces of his environment whose dehumanizing corrosive effect is presented through the poignant paradoxes of the 'salesman's death'.

\section{Social drama and the necessity for tragedy}

The fact is that well before Death of a Salesman, the tragic vision of American reality had marked American drama as it grew to maturity and shaped its distinctive styles and themes. With Miller however, this drama became even more concentrated on the theme of the social condition of the contemporary American individual living the paradoxes of the so-called 'American Dream'. In dealing with this theme, the combination of tragedy and social drama distinguishes Miller's play

Arab World English Journal for Translation \& Literary Studies 
AWEJ for Translation \& Literary Studies Volume, 3 Number 2. May 2019

Tragedy and social drama in Arthur Miller's Death of a Salesman Bayouli \& Sammali

from the other major representatives of the Ibsenian tradition including Bernard Shaw and John Osborne whose social dramas are certainly not categorized as tragedies. It is the fact that a tragic form is claimed and opted for in the dramatization of the social theme that places Death of $a$ Salesman in an outstanding position within this tradition of modern social drama. This distinction is obvious even in comparison to plays that comprise tragic elements. Indeed, the generic questions involved in a discussion of tragedy in Death of a Salesman are not the questions involved in discussions of any play by Eugene O'Neill or Tennessee Williams, also categorized as tragedies. The writer's article in defense of the tragic status of his play has certainly been a helping factor in the focus on the issue of tragedy from a generic point of view. The play's structure, the character and experience of its hero along with its ending, point to the generically self-conscious nature of the play. For as long as tragic form shapes the dramatic construct in its totality, the question of purity and authenticity of that form is inevitably involved, not because the play has to be measured against a set of generic requirements and conventions, but more importantly because the specific tragic effect wanted from such a form does not admit mixed tones and moods.

While admitting that Death of a Salesman is "a slippery play to categorize", Miller (1987) defended it against critics' attacks upon it as a "pseudo-tragedy": "I need not claim that this is a genuine solid-gold tragedy for my opinions on tragedy to be held valid" (p. 146). Many critics are now in the belief that the irrelevance of 'absolute tragedy' does not mean that tragedy has no place in modern drama. In Tragedy After Darwin, Freeman (2010) writes: "What consistently remains important about tragedy, is not its literary structure, but the sense that Western culture employs tragedy to understand itself when it is in crisis" (p.202). Tragedy needed a rehabilitation and an adaptation to the modern condition and most importantly to the essential shift in the nature of the forces that are presented as shaping the modern tragic hero's destiny. Grochaha (2012) writes "High tragedies are replaced by modern domestic tragedies, the heroes' tragic destinies are shaped not by Fate but by the equivalent to fate: the social, economic circumstances in which they live". (p.26)

In Death of a Salesman, it is obvious that the social and economic circumstances constitute from the very beginning the element that shapes the action and determines the role and tragic destiny of the main character. Therefore, the interrelation between the social theme and the tragic form in Death of a Salesman can enlighten the play's tragic texture by means of an examination of the dramatic process and above all, the kind of effect produced by the resolution brought to the theme of social protest. First, the play certainly stands out in ending with the death of the main character, an element that is quite uncommon and significant of the play's distinctive position in modern drama. The death of the hero is meant to bring a tragic closure to the play while functioning as a comment on the social reality portrayed from the start.

\section{Dramatic structure and effect}

With its blend of social drama and tragedy and its focus on the individual versus the system theme, Death of a Salesman meant to address the ethical crisis in the Western post-industrial society by dramatizing what is most deeply tragic in the predicament of the modern individual.

Arab World English Journal for Translation \& Literary Studies 
AWEJ for Translation \& Literary Studies Volume, 3 Number 2. May 2019

Tragedy and social drama in Arthur Miller's Death of a Salesman Bayouli \& Sammali

For this, it very much relies on the element of tragic tone and tragic effect while experimenting with new dramatic techniques and structures.

Most importantly, the death of the main character is meant to give the social drama in the play a tragic dimension. The nature of the dramatic use of death is the most important structural element that gives Death of a Salesman its distinctive place as the most typical tragedy of modern drama. Arthur Miller certainly introduces the death of the main character as the culmination of the action that gives the dramatic intensity and effect of tragedy. Yet, if the neo-classical, most notably the Elizabethan drama, established the death of the hero as the archetypal tragic situation, the characteristics and orientations of modern drama are such that death no longer has this kind of presence and function. In such a landmark of modern drama as Beckett's Waiting for Godot, death is a constant concern of the characters in their grappling with the inextricable issue of existence. However, when death seems to be preferred to life, it does not happen. Vladimir and Estragon cannot accomplish suicide because the rope they use to hang themselves is too short and is needed to keep Estragon's trousers up, and the situation turns to farce. In fact, unlike in Miller's play, death in Waiting for Godot is not given a tragic but a parodic and comic treatment. The distinction here is between an ontologically oriented drama showing death and life as equally absurd and Miller's social drama that uses the death of the protagonist as a supreme expression of the tragic in the modern individual's reality. Discussing the place of tragedy in modern drama, Wallace (2010) contrasts what she calls "American tragedy" to Beckett's plays described as "tragic parodies of modernity" (p.13).

In fact, nothing is more significant of the radical shift in the conception and the dramatization of the tragic than the fact that real death seems to become irrelevant on the modern stage. The contrast can be still more instructively seen through a comparison between Death of a Salesman and other American plays of the same period. In many of these plays, death is introduced in a dramatic process that is primarily psychological. If it occurs, it is imaginary and allegorical and is connected to a decisive moment of psychological regeneration and rebirth. Death is then the culmination of a whole process, which is psychoanalytical. The death of the child in Edward Albee's Who's Afraid of Virginia Woolf is a good instance of this. A shift to optimistic pragmatism is probably the explanation of this orientation in American drama represented by Albee's plays. The emphasis is on an active and constructive role given to the individual in bringing about some kind of regenerative change. The play's concerns are psychoanalytical in addition to being sociopolitical. It achieves its effect by means of a 'happy ending' that introduces a message of hope and faith placed in the individual as an agent of change. In exposing the state of alienation of the character, the American playwrights, including Arthur Miller, tend to attribute it to the oppressiveness of an encroaching social order. Rather than just showing the individual as confronting the system, the tendency in Albee's plays is to evolve an emotional and psychological process, which shapes the dramatic development and ultimately regenerates the individual through an awakening and breaking with the illusions of recognized false values. In Death of a Salesman, this element of awakening is excluded from the central character's role, precisely because it would not be in keeping with the coherently developed character of Willy Loman as 'the common man' and Willy is meant to embody to the end the notion of tragic blindness. The fact that the element

Arab World English Journal for Translation \& Literary Studies 42 ISSN: 2550-1542 | www.awej-tls.org 
AWEJ for Translation \& Literary Studies Volume, 3 Number 2. May 2019

Tragedy and social drama in Arthur Miller's Death of a Salesman Bayouli \& Sammali

of awakening or recognition is eventually introduced and is shifted to the second character Biff, may be explained by the fact that a thoroughly tragic form is felt to be insufficient for the modern spirit of pragmatism and optimism.

\section{Psychological realism and the function of the retrospective technique}

It is thus noticeable that Death of a Salesman denies its hero recognition and change but sets out to show his death as inevitable in the light of his being a coherently developed psychological entity. Miller's play displays this tendency of post-war American drama in its psychological orientation. Yet, the introduction of expressionistic elements in a realistic framework distinguishes the play in its psychological dimension. A central device in the dramatization of the protagonist's state of mind is Miller's ingenious handling of time. The action begins quite realistically in the present with Willy Loman returning home from his day's frustration, and as it becomes obvious that the focus is primarily psychological, the technical means of staging it becomes clear. Quite unexpectedly in the third act, the characters appear younger thus indicating a flashback in time. This is in fact no interruption of the present by a shift to a past action, but still part of the present, a moment in the current dramatic process in which what is presented on stage becomes an internal kind of action, an action of the mind. In The Legacy of Miller, Otten (2012) interprets these memory scenes in terms of the impossibility to elude what she calls the "Presentness of the past" and Miller's use of "the elemental condition of tragedy that there are inevitable consequences to our choices, which constitutes the moral spine of his dramas" (p.141). However, Miller's use of this past-into-present technique cannot be rightly understood without linking it to the essentially satirical and political purpose of the playwright. Interpreting Miller's integration of retrospective technique and tragedy in moral terms would be a misreading of the nature of his drama, and as Otten (1999) asserts, Miller himself views his "artistic end in Death of a Salesman as closer to Ibsen than to Sophocles" (p. 286).

It is obvious that the function of this presence of the past in the play is primarily psychological and is meant to show the progression of Willy towards his inevitable tragic end. The technique of the memory scenes makes the audience quite naturally follow Willy's mind each time it delves into the past or surges off dreaming. In the introduction to his Collected Plays, Arthur Miller says that he initially thought of "The Inside of his Head" as a title of his play. The playwright is so entirely devoted to dramatizing the reality of the protagonist that what is lived internally and what goes on in his mind in the form of memory or hallucination are all acted out on the stage. This way, an internal or psychological type of realism superimposes external realism that first marks the play. What is remarkable is Miller's exploitation of the technical possibilities of the modern stage including alternation of offstage and onstage scenes, carefully calculated shift and focus of lighting, visual and sound effects. These tools are efficiently handled to achieve a total flow of action with a double dimension, the immediate/actual and the retrospective/mental. This elaborate fusion of past with present does not only proceed from the premise that the difficulties of the present have their roots in the past. It is also used as a device to dramatize the invisible workings of Willy's mind. It aims at giving a full image of the character's alienation; an image of a mind that has sunk into unreality and is shrinking from confronting the imminent truth and indulging in

Arab World English Journal for Translation \& Literary Studies 
AWEJ for Translation \& Literary Studies Volume, 3 Number 2. May 2019

Tragedy and social drama in Arthur Miller's Death of a Salesman Bayouli \& Sammali

selective recollections of the past. The isolation of the character from the world around him is only increased by self-delusion as he refuses to recognize what is really wrong in his life.

Thus, the function of the memory scenes are twofold. They are first expository in that they contain information about the character's past life. Second, they are analytical as they explain his situation by showing its underlying causes in the past choices of the character. These latter are socially and culturally determined since they are fostered by a set of values fixed by a system seen to be oppressive and deceptive. Information about Willy's past also sheds light on his son Biff whose character is shaped by his father's obsessive interference, thus preparing the ground for the father-son relationship to occupy a central place.

More importantly, and as long as Willy is concerned, the memory scenes are necessary in the dramatization of a continuous psychological process, as they show Willy increasingly sinking into emotional and mental alienation. It also becomes apparent along the play that what is at stake is Biff's as much as Willy's psychological balance. The action propels the elder son to the role of a potential agent of change as he realizes that it is vital for his own as well as his father's redemption that the latter be brought back to reality. Within the tragic structure of the play, the memory scenes constitute an episode in Willy's tragic struggle not to collapse in defeat and to maintain a sense of dignity through re-visiting what he sees as a glorious past.

\section{A place for recognition}

The encounter between Willy and his sensitive neighbor Bernard offers a first glimpse at recognition as the only process by which things might change. It is then duplicated at a more emotional and dramatic level in the encounter between father and son. Recognition resulting from a confrontation within a domestic conflict is a key element in the plays of the two most important contemporaries of Miller: Tennessee Williams, and Edward Albee. In such plays as Cat of a Hot Tin Roof and Who's Afraid of Virginia Woolf, confrontation is instrumental in stirring a numbed conscience and extracting the individual from the trap of fantasy and illusion. The process involves a character whose fate is tied to the chief protagonist (George in Who's afraid of Virginia Woolf and Big Daddy in Cat on a Hot Tin Roof). This is the role that, in Death of a Salesman, Bernard undertakes for some time before Biff in turn does. In a kind of interrogation that sounds in keeping with his newly established image as a prominent lawyer, Bernard questions Willy about a precise fact in the past which underlies Biff's abject stance in life but to which Willy remains insensitive. The scene stands as an ironic counterpart to all the scenes of the past lived individually by Willy. For the first time in the play, the past can no longer be a refuge for Willy's faltering mind but is at the heart of a possibly factual recognition, which might awake him to his present realities. This casual confrontation is nevertheless inconclusive and is interrupted before reaching a possible turning point and this is where Death of a Salesman differs from the other two plays.

Rather than bringing a resolution to the psychoanalytical process, the play takes a turn towards a tragic ending that gives a tragic resolution to the social theme. The last confrontation between Biff and Willy is not conclusive even though it is prepared for by the emphasis on the great intensity of the relationship between father and son. Willy seems to stand at the crossroad of a

Arab World English Journal for Translation \& Literary Studies 
AWEJ for Translation \& Literary Studies Volume, 3 Number 2. May 2019

Tragedy and social drama in Arthur Miller's Death of a Salesman Bayouli \& Sammali

psychologically redeeming process and an ultimate form of alienation that is suicide. The play emphasizes the presence of the two alternatives. For a certain time, hope is raised for Willy's awakening yet it is frustrated by his repeated failure to respond to or understand Biff. Fixed on the idea of redeeming himself from the unbearable perspective of what he sees as undeserved failure, his mind is incapable of seeing things in any terms other than material achievement. Redemption is for him in an act of self-sacrifice that, as he tells his dead brother Ben in yet another hallucination scene towards the end of the second act, can change "all the aspects".

Unlike the plays of Tennessee Williams and Edward Albee, the psychological process in Death of a Salesman is undercut by the play's orientation towards a tragic end as it establishes Willy's mental reactions as inevitably self-destructive. This functions as a tragic flaw leading to tragic blindness. The confrontation has fostered Biff as having an insight and recognition of which Willy seems incapable. This is one of the arguments put forward by some critics to deny the play its tragic status. However, such a view does not seem to take into account a major feature of the play that is the duality of its dramatic structure and effect. Biff is represented as a parallel center of interest to Willy in this phase of the action but it is obvious that it is Willy who is destined to the role of the central figure accomplishing the play's tragic structure. Willy's last act maintains the consistency of tragic blindness leading to his tragic end. The final scene is structured as to give the play the dimensions of tragedy. The element of identification and cathartic effect are ensured by the fact that Willy's tragic end is brought about by feelings that are fully human and universal. The recognition element is associated with Biff and is retained to a post-tragic phase in the 'Requiem' scene. This double aspect marking the play's resolution- Willy's tragic blindness and Biff's recognition is central to the play's message about the individual versus the system theme, even though it constitutes in our sense, an element of weakness in the tragic structure.

In fact, the final scene is poignantly marked by the lonely figure of a man racing into his death with the exalted spirit of victorious achievement. Change and recognition seem insignificant and invalid since they would have been contradictory to a coherently developed psychological entity. In Willy's perception, salvation from failure, guilt and self-betrayal can only be achieved through an act of self-sacrifice to signify his triumph upon life and the system. Arthur Miller seems to privilege here again a certain psychological realism. In the light of his characterization throughout the play, Willy Loman must not be capable of the insight and recognition allowed another character like his son Biff, yet he is not shown as the kind of man to surrender passively. Commenting on the tragic status of his play, Miller (1957) writes:

I did not realize how few would be impressed by the fact that this man is actually a very brave spirit who cannot settle for half but must pursue his dream of himself to the end. ... I thought it must be clear, even obvious, that this was no dumb brute heading mindlessly to his catastrophe. (p.34)

It is remarkable that the terms of the debate about tragedy seem to figure within the play itself. Biff shouts these words at Willy as he discovers his planned act:"What is this supposed to do, make a hero out of you? This supposed to make me sorry for you? (...) There'll be no pity for you, 
AWEJ for Translation \& Literary Studies Volume, 3 Number 2. May 2019

Tragedy and social drama in Arthur Miller's Death of a Salesman Bayouli \& Sammali

you hear it? No pity"(p.104). Earlier, the visiting figure of Ben has warned him: "It's called a cowardly thing, William." (p.100) But, it is in remaining alive that Willy would see himself as cowardly. Hallett (1978 p.21) links the inadequacy of the tragic role of Willy to the absence of transcendence consisting in what he describes as "something beyond human comprehension" in the hero's tragic experience. However, Willy is certainly not destined to embody the transcendental type of tragic hero. The Hamlet dilemma of "to be or not to be" is for Willy easily resolved because transcendental "conscience" is not there to complicate his decision. Willy's intellectual limitations indeed confirm his tragic flaw and sustain the meanings of his tragic role.

In the last scene, triumph is for the other characters merely the work of Willy's fantasy and self-delusion, but in Willy's soul and mind it is tangible and real enough as he says to the visiting Ben with the tone of exalted victory:

Oh, Ben, that's the whole beauty of it ! I see it like a diamond, shining in the dark, hard and rough, that I can pick up and touch in my hand.

( Act II, p.100)

Most importantly, Willy gains tragic stature through the intensity of his experience as a human being who is left no other alternative but to seek assertion of his self and sense of dignity in suicide. It may be contended that Willy falls victim of his own delusions, but it is an undeniable fact that something of hubristic pride and bravery characterize him especially in the last scene. Indeed an essential aspect of his characterization as a tragic figure is the fact of being the common man while having a mythic image of himself and of his sons, and, as such, in Miller's own words he "cannot settle for half'(1949 b p.2). His struggle to redeem himself and his son from defeat is what makes his tragic end ennobling and exalting, no matter how futile his attempt is.

The Requiem scene is in a certain sense, the element of weakness in the play's dramatic structure and specifically the role attributed to Biff. In contrast to his father, Biff seems to be vindicated by a change he has undergone in his character and outlook. And it is through confronting reality that he achieves the self-knowledge he repeatedly stresses. However, although Willy is not allowed conventional anagnorisis, his character comprises an element of mystery and uniqueness that aggrandizes his tragic stature. He too struggles all along the play to face harsh reality but rather than withdraw or surrender, he chooses an ultimate act of self-assertion that is also an act of self-sacrifice and expression of love. Audiences naturally identify with his tragic plight as a man who, in Harold Bloom's words "wants only to earn and to deserve the love of his wife and of his sons" and who is "self-slain not by the salesman's dream of America, but by the universal desire to be loved by one's own"(2007 p.38). The final tragic scene becomes the assertion of Willy's true self and his tragedy exemplifies what Arthur Miller describes as "the tragedy of displacement" in which "the tragic dimension surfaces in the protagonist's struggle for a lost personal identity displaced by the social mask" (Conversations, 347).

However, if the final scene in Willy's life brings the play to a climax of tragic effect, the meanings associated with Willy's tragic end and the intensity of its tragic effect are undermined

Arab World English Journal for Translation \& Literary Studies 
AWEJ for Translation \& Literary Studies Volume, 3 Number 2. May 2019

Tragedy and social drama in Arthur Miller's Death of a Salesman Bayouli \& Sammali

by the Requiem that comes as a post-tragic-end sequel to the play. Biff announces that he is going West to lead the kind of life he described in Act I in terms of a romantic longing which has always been one of Willy's vaguely sensed dreams:

This farm I work on, it's spring out there now, see? And they've got about fifteen new colts. There's nothing more inspiring or beautiful than the sight of a mare and a new colt. And it's cool there now, see? Texas is cool now, and it's spring.

(Act I p.11)

This pastoral dream is about an America that is shown throughout the play to be superseded by an increasingly urban and commercial America. Biff also complains: "We don't belong in this nuthouse of a city! We should be mixing cement on some open plain, or - or carpenters. A carpenter is allowed to whistle" (p.22). The son in fact withdraws from the social reality that his father has tragically confronted and the stance Biff finally assumes turns out to be an evasion of the conflict raised. The juxtaposition of two responses to this conflict that are opposed in nature is the source of weakness in the tragic construct. Had the tragedy been without the "Requiem", it would have better preserved its unity and the coherence of its message.

To conclude, the domestic setting, and the dramatization of the everyday life of common people are elements that ground Death of a Salesman in modern realism and social drama more specifically. Yet, analysis shows that the play is meant to take on dimensions of tragedy that are essentially achieved through the turn of the action towards a tragic ending. Most importantly, the final act brings the play to a climax of tragic effect with the figure of its protagonist seeing in death the assertion of his self and the realization of his sense of dignity. The play succeeds in making social drama acquire the intensity and the universal cathartic effect of tragedy and this is perhaps the magic that lies behind its perennial appeal to audiences identifying with the experience of its hero. The controversy about the play as tragedy may never be closed but this paper came to the assertion that 'tragedy as social drama' is quite an accurate definition and interpretation of Miller's play. Examination of the Requiem has revealed that such a post-tragic-end weakens the tragic effect, as it comprises an element of dramatic irony and ambivalence with the characters expressing their divergent responses to Willy's death. Thus, Death of a Salesman gives evidence that a nontainted resolution is necessary for the tragic construct to preserve the force of its effect and the coherence of its message. The temptation of the regenerative, perspective-opening 'happy ending' seems to lie behind the adding of such a post-tragic Requiem, making the play fluctuate between a wholly tragic from and a second ending that undermines the tragic effect.

\section{Acknowledgements:}

The authors would like to thank the Deanship of Scientific Research at Majmaah University for supporting this work under the project: (1440-89).

About the authors:

Tahar Bayouli is an assistant lecturer of English language and literature at the Department of English, Azzulfi College of Education, Majmaah University, KSA. He obtained his PhD from the

Arab World English Journal for Translation \& Literary Studies 
AWEJ for Translation \& Literary Studies Volume, 3 Number 2. May 2019

Tragedy and social drama in Arthur Miller's Death of a Salesman Bayouli \& Sammali

University of Paris West France in 1994. Thesis "The Image of the Orient in Elizabethan Drama". His research interests include drama, semiotics and orientalism.

Imed Samaali is currently a lecturer of English language and Applied Linguistics at the Department of English, Azzulfi College of Education, Majmaah University, KSA. He obtained his Master's Degree from the Faculty of letters, Arts and Humanities Manouba, Tunisia in 2011. He taught from 2011 to 2014 at the Higher School of Economic and Social Sciences of Tunis, Tunisia. https://orcid.org/0000-0001-6173-8840

\section{References:}

Bentley, E. (1976). 'In Search of Theater' in Death of a Salesman: Text and Criticism ed. Gerald Weales Penguin, New York,

Bloom, H. (2007). Modern Critical Views: Arthur Miller InfoBase Publishing

Cohn, R. (1969).Currents in Contemporary Drama Indiana University Press

Durrenmatt, F. (1958). Problems of the Theatre, Transl. G. Nelhaus New York

Fiet, L. A. (1976). The tragic Fallacy Revisited The Journal of Aesthetic Education $10(1)$

Freeman, S. (2010).'Tragedy after Darwin' Comparative Drama 44 (2)

Grochaha, S. (2012). 'Tragedy Now?' In Visions of Tragedy in Modern American Drama Edited by David Pahna

Hallett, C. A. (1978). "The retrospective technique and its implications for tragedy" Comparative Drama 12 (1)

Maeterlinck, Maurice: (1952) Le Trésor des Humbles, translated by K. Eliott Oxford

Miller, A. (1998) Death of a Salesman, Penguin Twentieth century Classics New York

Miller, A. (1949). "The Tragedy of the Common Man" The New York Times, 27 http://movies2.nytimes.com/books/00/11/12/specials/miller-common.html

Miller, A. (1957). Introduction to Collected Plays Viking Press

Miller, A. (1987). Conversations with Arthur Miller ed. By Matthew C. Roudané, Jackson, Mississippi University Press

Otten, T. (1999). "Death of a Salesman at fifty: Still coming home to roost" Texas Studies in Literature and Language 41 (3) (2012) "The Legacy of Arthur Miller" The Arthur Miller Journal 7 (1/2)

Schmidt, D. (2001). On Germans and Other Greeks: Tragedy and Ethical Life Bloomington Indiana University Press

Sewall, R. B. (1954). "The Tragic Form" in Essays in Criticism 6 (October)

Steiner, G. (1961). The Death of Tragedy Faber and Faber London

Styan, J. L. (1968). The Dark Comedy Cambridge University Press

Wallace, J. (2007). The Cambridge Introduction to Tragedy. Cambridge U. P.

Arab World English Journal for Translation \& Literary Studies 